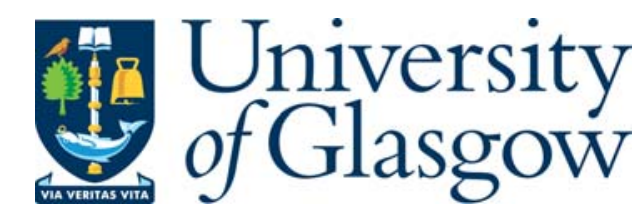

Harrison, V.S. (2007) Internal realism, religious pluralism and ontology. Philosophia 36(1).

http://eprints.gla.ac.uk/3853/

Deposited on: 03 December 2007 


\section{Internal Realism, Religious Pluralism and Ontology}

Internalist pluralism seeks to provide a theoretical account of religious diversity; ${ }^{1}$ as such it is a version of religious pluralism. Specifically, it has been advanced as an alternative to transcendental religious pluralism, which is the form of pluralism famously advocated by John Hick. ${ }^{2}$ Despite the many appealing features of internalist pluralism, its viability as an alternative to rival theories of pluralism will depend upon how successfully it can respond to criticism.

In this article I defend internalist pluralism against two possible, yet seemingly contradictory, criticisms to which the theory, at first sight, can appear vulnerable. The first objection claims that the resulting analysis of religious belief systems is intrinsically atheistic. The second objection claims that the analysis is unsatisfactory because it involves simply defining into existence various religious objects. (In other words, the critic of internalist pluralism charges that important ontological questions are decided by definitional fiat.) Interestingly, it is those of a religious persuasion who often presume that internalist pluralism is inherently atheistic; whereas it is those who are inclined towards atheism who tend to presume that internalist pluralism simply defines Gods and other purported religious entities into existence. I suspect that one reason for this is that both religious believers and atheists tend to take metaphysical realism for granted. But internalist pluralism seemingly leaves one, at best, with an internally real God, which appears to be ontologically less substantial than the metaphysically real God that many believers think they need; while atheists, holding that — in metaphysically realist terms - the world is devoid of any God, find any talk of an internally real God unacceptable.

\footnotetext{
${ }^{1}$ For a detailed exposition of internalist pluralism, see Victoria S. Harrison, "Internal Realism and the Problem of Religious Diversity", Philosophia 34, 3 (2006): 287-301.

${ }^{2}$ For the most sophisticated account of Hickean transcendental pluralism, see John Hick, An Interpretation of Religion: Human Responses to the Transcendent (London: Macmillan, 1989).
} 
In what follows, I demonstrate that a subscriber to internalist pluralism can deflect both objections, and in the course of so arguing, I deploy a distinction between the "conceptual-scheme targetable" and the "successfully conceptual-scheme targeted".

\section{II}

What, then, more precisely, is internalist pluralism? It is an adaptation to the religious domain of internal realism - a theory first advanced by Hilary Putnam. ${ }^{3}$ Like the Putnamian internal realist, the adherent to internalist pluralism holds both that whichever objects can be said to exist is conceptual-scheme ${ }^{4}$ dependent and that whatever it means for an object to exist is equally conceptual-scheme dependent. Putnam gives the example of a world containing three atoms. ${ }^{5}$ A "Carnapian" sees a world of three objects, whereas a "Polish Logician" sees a world of seven objects (the atoms and the mereological sums of two or more atoms). Figure 1 represents a world of three atoms (let us call it "W1") as seen by a "Carnapian", and Figure 2 represents a world of three atoms as seen by a "Polish Logician", who also sees three pairs and a trio (the mereological sums of those three atoms). When a "Carnapian" claims that the world contains only three objects, a "Polish Logician" may well mistakenly conclude that the "Carnapian" believes that the world contains two atoms. For a "Polish Logician" would regard a world containing three objects as only comprising two atoms and one pair (the two atoms and their mereological sum). Let

\footnotetext{
${ }^{3}$ See, particularly, Hilary Putnam, Reason, Truth and History (Cambridge: Cambridge University Press, 1981) and Hilary Putnam, Realism with a Human Face, edited by James Conant (Cambridge, Massachusetts: Harvard University Press, 1992, first published 1990). The purpose of this paper is not to elucidate Putnam's views. Hence, here I appeal exclusively, although not exhaustively, to those aspects of his thought which seem particularly salient to the development of internalist pluralism.

4"Conceptual scheme" is a term of art within recent Anglo-Saxon philosophy. Most philosophers would agree that a conceptual scheme can be defined as the "general system of concepts with which we organize our thoughts and perceptions." Simon Blackburn (ed.), Dictionary of Philosophy (Oxford: Oxford University Press, 1996), p. 72.

${ }^{5}$ See Hilary Putnam, Renewing Philosophy (Cambridge, Massachusetts: Harvard University Press, 1992), p. 120.

${ }^{6}$ The "Polish Logician" is so called because of his debt to the language developed by the Polish logician, and founder of mereology, Stanislaw Lezniewski (1886-1939).
} 
us call a world containing two atoms "W2". If the "Carnapian" were to consider W2, however, he would claim that it contains only two objects.

Conversely, upon hearing the "Polish Logician" declare that a world contains seven objects, the "Carnapian" might mistakenly conclude that the "Polish Logician" believes that world to contain seven atoms. Let us call a world containing seven atoms "W3". Clearly, what the "Carnapian" and the "Polish Logician" disagree about is what is to be counted as an "object". And according to internal realism, what is to be counted as an object is conceptual-scheme dependent. The problem is that the "Carnapian" and the "Polish Logician" think within different conceptual schemes. And this can lead to the "Carnapian" mistakenly thinking that the "Polish Logician" is wrongly describing the world as if it were W3, and to the "Polish Logician" mistakenly thinking that the "Carnapian" is wrongly describing the world as if it were W2.

According to internal realism, then, one's choice of conceptual scheme determines what is to count as an object. But this must imply that one's choice of conceptual scheme also determines what it is to count as existing. For according to the "Carnapian", only three objects exist in W1; while according to the "Polish Logician", within W1 seven objects exist. Hence, what it is to exist must be no less conceptualscheme dependent than what is to count as an object. But this doesn't thereby turn W1 into either W2 or W3. We could put the claim of conceptual-scheme dependence this way: the conceptual scheme of the "Carnapian" ensures that only atoms are in principle "targetable"; whereas the conceptual scheme of the "Polish Logician" makes both atoms and their mereological sums in principle "targetable". But although one's conceptual scheme determines what kind of entity is targetable, one's conceptual scheme does not thereby on its own ensure that anything will actually be targeted. For even if both atoms and their mereological sums are targetable, there might be neither atoms nor mereological sums to target. ${ }^{7}$ Hence, conceptual-scheme dependence does not simply bring things into existence ex nihilo. ${ }^{8}$

\footnotetext{
${ }^{7}$ Put another way, one might say that whether or not an entity has been successfully targeted is a fact while whether or not an entity is targetable is a convention. Moreover, successful targeting is not entailed by mere targetability.

${ }^{8}$ Commenting on this example in a recent work, Putnam writes: "Saying that there are three objects in the universe of discourse Carnap was describing is a matter of fact, as opposed to saying that there are four objects in that universe, and a matter of convention, as opposed to describing the situation in
} 
However, when one moves from the "Carnapian" conceptual scheme to the conceptual scheme of the "Polish Logician", it might be thought that mereological sums are indeed brought into existence. But any such assumption is likely to be extremely misleading. For if one formerly subscribed to the conceptual scheme of the "Carnapian", then in moving to the conceptual scheme of the "Polish Logician", one does not bring into being mereological sums that exist in the way in which objects exist within the "Carnapian" conceptual scheme. Rather, one's understanding of what it is to exist changes when one moves from the conceptual scheme of the "Carnapian" to that of the "Polish Logician". Equally, if one had previously subscribed to the conceptual scheme of the "Polish Logician", then in moving to the "Carnapian" conceptual scheme one does not extinguish mereological sums in terms of how they exist within the conceptual scheme of the "Polish Logician". Again, it is rather that one's understanding of what it is to exist might change when one moves from one conceptual scheme to the other. ${ }^{9}$ Hence, any assumption that one either brings objects into existence or extinguishes them as a result of switching conceptual schemes rests on an equivocation between two conceptions of existence. Because the conception of existence alters as one moves from the "Carnapian's" to the "Polish Logician's" conceptual scheme, one would be equivocating between two conceptions of existence if one were to assume that entities were either brought into existence or extinguished merely by virtue of one's choice of conceptual scheme. ${ }^{10}$ Hence, there is clearly a

Lezniewski's language by saying that there are seven objects (counting the mereological sums as objects)." Hilary Putnam, Ethics Without Ontology (Cambridge, Massachusetts: Harvard University Press, 2004), p. 45. In other words, Putnam seems to be claiming that what is targetable is a matter of convention, while what is successfully targeted is a matter of fact.

${ }^{9}$ As Putnam explains: "to ask whether mereological sums really exist would be stupid. It is, in my view, a matter of convention whether we say that mereological sums exist or not. But what does this mean? How can the question whether something exists be a matter of convention? The answer, I suggest, is this: what logicians call 'the existential quantifier,' the symbol '( $\mathrm{E} x)$,' and its ordinary language counterparts, the expressions 'there are,' 'there exist' and 'there exists a,' 'some,' etc., do not have a single absolutely precise use but a whole family of uses." And he continues, "there is nothing in the logic of existential and universal quantification to tell us whether we should say that mereological sums exist or don't exist; not is there some other science that answers this question. I suggest that we can decide to say either". Putnam, Ethics Without Ontology, ibid., pp. 37f.

${ }^{10}$ In other words, to use Eli Hirsch's terminology, internal realism argues for "quantifier relativity". See Eli Hirsch, Dividing Reality (Oxford: Oxford University Press, 1993). 
sense in which the "Polish Logician" does not create new entities to be counted simply by employing a particular conceptual scheme. ${ }^{11}$ That there are objects at all depends upon what is successfully targeted by one's conceptual scheme. But which entities are targetable is wholly conceptual-scheme dependent. ${ }^{12}$

To take an example from the religious domain, when one moves from a Theravada Buddhist conceptual scheme to the conceptual scheme of a Christian, it might be thought that certain entities are brought into existence. One would be moving from a conceptual scheme which did not recognize the existence of either a supreme God or any human selves, to one in which the existence of both God and selves was affirmed. However, according to internalist pluralism, if one formerly subscribed to the conceptual scheme of a Theravada Buddhist, then in moving to the conceptual scheme of a Christian, one does not bring into being either a God or selves. Rather, internalist pluralism suggests that one's understanding of what it is to exist may well change when one moves from the conceptual scheme of a Theravada Buddhist to that of a Christian. Likewise, if one had previously subscribed to the conceptual scheme of a Christian, then in moving to a Theravada Buddhist conceptual scheme one does not extinguish either God or selves in terms of how they exist within the conceptual scheme of a Christian. Clearly, then, it would be mistaken to claim either that a Christian extinguishes entities in moving to a Theravada Buddhist conceptual scheme, or that a Theravadan creates entities to be counted simply by employing a Christian conceptual scheme. That there are selves and a God at all depends upon what is successfully targeted by one's conceptual scheme. But whether or not selves and a

\footnotetext{
${ }^{11}$ Alternatively, imagine that the "Carnapian" and the "Polish Logician" inhabit a world with no sun, no moon, and only three stars, and that they are counting the objects in the sky. Although the "Polish Logician" counts more objects than the "Carnapian" does, it is not because he employs a conceptual scheme that has allowed him, for example, to create more stars.

${ }^{12} \mathrm{~A}$ critic might object that this amounts to another version of what Putnam disparagingly terms the Cookie Cutter Metaphor. Do we divide up the fundamental stuff of the world (the dough) according to what is targetable by our conceptual schemes? The answer to this seem to be no. As explained above, just because an entity is targetable within some conceptual scheme does not entail that it will be successfully targeted by users of that conceptual scheme. According to the Cookie Cutter Metaphor, the use of a particular cookie cutter determines that part of the dough will take its shape. However, the mere employment of a conceptual scheme in which an entity is targetable does not entail that the entity will be successfully targeted.
} 
God are targetable is wholly conceptual-scheme dependent. A Theravada Buddhist conceptual scheme targets neither selves nor a God, whereas a Christian one does.

The ability of internal realism to differentiate between conceptual-scheme targetability and successful conceptual-scheme targeting distinguishes it from subjective idealism - a theory that tends to portray everything as wholly and simply conceptual-scheme dependent. According to internal realism, a conceptual scheme determines what one will identify as an object. But it does not ensure that such objects are there to be found. In other words, merely employing a particular conceptual scheme is no guarantee that the objects the scheme tells us to count are there to be counted. ${ }^{13}$ With respect to the example of the Theravada Buddhist and the Christian, a subjective idealist would claim that the differences between them are conceptualscheme dependent. An internal realist would agree, but with one important qualification: whether there are any objects to be counted depends both on what one's conceptual scheme renders targetable and also on what one can then successfully target. It is not simply a matter of everything being wholly conceptual-scheme dependent.

Allow me to adapt another example of Putnam's to illustrate the distinction between conceptual-scheme targetability and successful conceptual-scheme targeting.

\footnotetext{
${ }^{13}$ Allow me to adapt Alvin Plantinga's example of the Great Pumpkin to illustrate this point. One may imagine a conceptual scheme that holds the ultimate religious entity to be a Great Pumpkin. A subjective idealist might claim that the world perceived by those subscribing to this conceptual scheme is such that a Great Pumpkin is the ultimate religious entity, and that statements about the Great Pumpkin are true in this conceptual scheme. Plantinga's example was, of course, advanced as a reductio ad absurdum of such a conclusion. Plantinga believes that something has gone awry with a theory that commits us to taking beliefs about a Great Pumpkin seriously. It would seem, however, that internal realism can provide an analysis of conceptual schemes that avoids Plantinga's reductio. According to internal realism, the fact that some community subscribes to a conceptual scheme that holds the ultimate religious entity to be a Great Pumpkin does not make it the case that there must be a Great Pumpkin to which the claims of the members of the community successfully refer. Rather, given what the members of the community mean by "Great Pumpkin", and given what they mean by "ultimate religious entity", if there is such a Great Pumpkin, and if it is the ultimate religious entity, then the claims of those employing this conceptual scheme could be true. But the fact that some community employs this conceptual scheme does not automatically make their claims true, nor does it define the Great Pumpkin into existence. See Alvin Plantinga, "Reason and Belief in God", Faith and Rationality: Reason and Belief in God, edited by Alvin Plantinga and Nicholas Wolterstorff (Notre Dame: University of Notre Dame Press, 1983).
} 
Consider a world in which there are three large plants. One person may employ a conceptual scheme that draws no distinction between elms and beeches (for him, all trees are just trees). Thus he would see a world containing three trees, which he regards as large plants. But another person may employ a conceptual scheme that does distinguish between elms and beeches, both of which being regarded by her as large plants. She would see a world containing, for example, one elm and two beeches. The question of whether, along with the first person, we subscribe to a conceptual scheme that just identifies trees or, along with the second person, we subscribe to a conceptual scheme that identifies elms and beeches is quite distinct from the question of whether or not there are any large plants. The latter is, in this example, not simply conceptualscheme dependent in the way in which the question of whether there are just trees or whether there are elms and beeches is wholly a matter of the choice of conceptual scheme. $^{14}$

\section{III}

The fact that we can talk about such examples suggests that it is possible to learn to employ a new conceptual scheme ${ }^{15}$ — an implication that can be regarded as consistent with the phenomenon of conversion to a religion. ${ }^{16}$ Allow me to use another example to illustrate this point: Consider the fish charts that are available to help anglers and other interested parties learn to identify different species of fish. When the novice examines a fish chart, a common reaction is to declare that none of the catch matches any of the fish on the chart. However, with practice, and after having acquired a sufficient amount of relevant angling experience, a person can learn how to use the fish chart to identify fish. The fish have not changed, but the individual's perception of them has. The fish are now seen as instances of the species of fish identified by the chart. After acquiring the conceptual scheme represented by the fish chart, the

\footnotetext{
${ }^{14}$ This is not to suggest, however, that it will always be an easy matter to determine whether or not any particular issue is wholly a conceptual-scheme dependent one.

${ }^{15}$ It also suggests that we can choose to discard a conceptual scheme that we had previously employed.

${ }^{16}$ Conversion from one religious conceptual scheme to another is very difficult to explain if one accepts John Hick's transcendental form of religious pluralism. It is equally problematic for religious exclusivists, such as Alvin Plantinga, as well as for religious inclusivists.
} 
individual has no difficulty, when she pulls a fish out of the water, in correctly declaring "It's a trout" or "It's a carp". ${ }^{17}$

Consider an example of a difference that an internal realist would regard as wholly conceptual-scheme dependent: $C$ subscribes to a particular form of Christian conceptual scheme and sees her fellow humans as belonging to one of two mutually exclusive categories: the damned or the saved. Contrast $C$ with $M$, who subscribes to a secular, ethical conceptual scheme. $M$ also sees her fellow humans as belonging to one of two mutually exclusive categories: but her categories divide human beings into the good and the bad. Were $C$ and $M$ to engage in conversation on the topic of the two categories that human beings can fall into, they may be barely comprehensible to each other. However, the fact that neither assents to the other's claims does not on its own imply that at least one of them must be wrong. For the difference between them may be wholly conceptual-scheme dependent. ${ }^{18}$

\section{IV}

Some presume, however, that to claim that religious entities are conceptual-scheme dependent makes internalist pluralism inherently atheistic. From the standpoint of Christianity, for example, the criticism would seem to be that the God worshipped by Christians is not appropriately classified as an object that only exists within a Christian conceptual scheme. Rather, according to Christianity, God is transcendent to all conceptual schemes. Because internalist pluralism would appear to be committed to the denial that such a conceptual-scheme transcendent God could exist, from a Christian perspective it may well seem indistinguishable from atheism. In other words, from a Christian point of view, internalist pluralism can appear to entail the

\footnotetext{
${ }^{17}$ Surely, no one would accuse a person who has learnt to use a fish chart of defining "trout", "carp" and so on into existence.

${ }^{18}$ If such a difference were judged to be wholly conceptual scheme dependent, would that imply a form of relativism that would constitute a threat to pluralism? I have discussed this potential objection in "Internal Realism and the Problem of Religious Diversity", op. cit.
} 
straightforward denial that God exists. ${ }^{19}$ However, as I explain below, there is nothing to stop an adherent of internalist pluralism replying to this objection with the claim that the concept "transcendence" employed by the Christian is itself clearly conceptual-scheme dependent. For, surely, whatever it means for God to be transcendent to a conceptual scheme is itself determined by some conceptual scheme.

Moreover, an adherent of internalist pluralism would only be an atheist in disguise if she were a metaphysical realist in disguise. For when an adherent of internalist pluralism states that (as in Figure 1) there are three objects according to the "Carnapian" conceptual scheme, and seven objects (as in Figure 2) according to the "Polish Logician's" conceptual scheme, she is not claiming that, really, there aren't any objects. Hence, why presume that an adherent of internalist pluralism must be committed to the claim that, really, there aren't any religious entities? Only if one presupposes metaphysical realism would one find the "reality" of a conceptualscheme dependent God questionable. ${ }^{20}$

In short, the first objection to internalist pluralism - that it is inherently atheistic only has bite if we presuppose metaphysical realism. But, obviously, one who subscribes to internalist pluralism does not share this presupposition. Internalist pluralism does indeed claim that God does not exist in the sense of existence subscribed to by a metaphysical realist about God, such as William Alston. ${ }^{21}$ But this is not enough to justify the charge that internalist pluralism is inherently biased towards atheism. Indeed, internalist pluralism regards the atheist's claims to be no less conceptual-scheme dependent than are the claims of religious believers.

Let us now turn to the other main objection to internalist pluralism: An atheist may well object that an adherent of internalist pluralism simply allows religious believers to define religious objects into existence and, in so doing, has undermined

\footnotetext{
${ }^{19}$ This appears to have been the understanding of the program board for a British Society for the Philosophy of Religion conference on religious pluralism. A talk on internalist pluralism was scheduled to take place in the "atheism" section of this conference.

${ }^{20}$ Admittedly, if theism is taken to presuppose metaphysical realism, then internalist pluralism is atheist at least in comparison to theism so construed. However, surely the claim that theism presupposes metaphysical realism simply begs the question of the most appropriate metaphysical framework within which to conceptualize theistic forms of religion.

${ }^{21}$ For an account of the form of metaphysical realism favored by Alston, see William P. Alston, $A$ Sensible Metaphysical Realism (Milwaukee, Wisconsin: Marquette University Press, 2002).
} 
the possibility of meaningful debate between believers and non-believers. ${ }^{22}$ Curiously, religious exclusivists could raise a similar objection. They might claim that allowing religious believers to define religious objects into existence commits the adherent of internalist pluralism to accepting all the ontological claims made by religious believers within every religious tradition as on a par-and that would surely undermine the possibility of meaningful debate between members of different religious traditions. ${ }^{23}$

Does internalist pluralism involve defining religious objects into existence, then? If so, it would provide cheap answers to important ontological questions, and thus would, in my view, rightly be regarded as an implausible theory by atheists and believers alike. In the following, I argue that internalist pluralism does not simply define religious objects into existence, and that it can, in fact, provide non-trivial answers to ontological questions. ${ }^{24}$

\section{V}

In order to ascertain whether or not internalist pluralism defines religious objects into existence, let me return to Putnam's example of a world comprising three atoms. Because the "Polish Logician" is looking for mereological sums (for example, pairs, trios, and quadruples) as well as atoms, she sees a different world to that perceived by the "Carnapian" (who is only looking for atoms). For the "Carnapian", only atoms are salient. But, for the "Polish Logician", mereological sums are just as salient as atoms. Figure 1 represents how the "Carnapian" sees a world comprising three atoms, while

\footnotetext{
${ }^{22}$ This objection was raised by Franz-Peter Griesmaier in response to a paper given at the University of Wyoming in 2004.

${ }^{23}$ This criticism was suggested to me by Jim Cook.

${ }^{24}$ This objection may be in part motivated by the mistaken belief that internalist pluralism is committed to the view that all statements religious people make concerning their faith are true relative to the conceptual scheme of that faith. I have argued against this erroneous understanding of internalist pluralism in "Internal Realism and the Problem of Religious Diversity", op. cit. However, if, contrary to fact, it were the case that all statements made about entities thought to exist within some religious conceptual scheme were true provided only that they were uttered by those subscribing to that conceptual scheme, that would indeed seem to lay internalist pluralism open to the charge of allowing entities to be defined into existence.
} 
Figure 2 attempts to represents how the "Polish Logician" sees a world with the same number of atoms: namely, as a world comprising three atoms, three pairs, and one trio.

Now, the differences between how those of different religious faiths conceptualize religious entities may well be analogous to the difference between Figure 1 and Figure $2 .^{25}$ The "Carnapian" and the "Polish Logician" do not agree on what is to be counted as an object, and followers of different faiths do not agree on what is to count as God or a God. So, consider the conceptual schemes employed by Muslims, Christians and Hindus. ${ }^{26}$ By comparing a world containing a tripartite God, angels and humans, with a world containing a non-tripartite God, angels and humans, when God, angels and humans are taken to comprise all the various targetable or countable agents, we can see how Muslims and Christians may easily see quite different worlds, for they view divine entities differently. If a world containing a tripartite God, angels and humans, is the world viewed by the Christian, and a world containing a non-tripartite God, angels and humans, is the world viewed by a Muslim, then the worlds of the Muslim and the Christian appear to differ in an analogous way to how the worlds of the "Carnapian" and the "Polish Logician" differ. So, while both traditional Muslims and traditional Christians agree that God may send instructions through angels, the Christian, unlike the Muslim, views God as a divine trinity that, mysteriously, is nevertheless a unity. If the Christian is correct in seeing a triune God, then should the Muslim fail to see such a God, that is not necessarily a mistake on her part. For the "Carnapian" is not making a mistake in seeing the world as in Figure 1 and failing to see the pairs and trio as in Figure 2.

Moreover, both the Muslim and the Christian view divine entities differently to the Hindu. However, the difference between the Christian and the Hindu is not the

\footnotetext{
${ }^{25}$ The following discussion concerns the dispute between atheists and those who subscribe to various forms of theism. However, it should be clear that the theory outlined could be applied to other forms of religious conceptual scheme-including non-theistic ones.

${ }^{26}$ The following characterization of the "Christian" view and the "Hindu" view are not offered as accurate representations of what all Christians or all Hindus actually believe. Not all Christians subscribe to trinitarianism, just as not all Hindus accept a tripartite characterization of God. Both views are, however, relatively common.
} 
same as the difference between the Christian and the Muslim. ${ }^{27}$ Like the Christian, the Hindu sees a world containing a tripartite God, angels and humans, and not a world containing a non-tripartite God, angels and humans. But the divine entities that the Hindu claims exist are not those that the Christian claims exist. For the Hindu regards the Absolute (God) as Brahman, who is projected as the Hindu trimutri of Brahma, Shiva, and Vishnu, and as many other Gods. But the members of the holy trinity, according to the Christian, are not projections. God the Father, for example, is Godas are God the Son and God the Spirit. The Christian and the Hindu agree on the number of countable religious entities, but they disagree both on what those entities are and on their ontological status.

But what of the difference between the atheist and the believer? This is not at all like the difference between the "Carnapian" and the "Polish Logician". The atheist could insist that that she understands well enough the Muslim, Christian and Hindu conceptual schemes, and hence that she well understands what each of them considers to count as God or a God, but that there is no such object or objects to be counted. In other words, the difference between the believer and the atheist is not like the difference between Figure 1 and Figure 2, but rather like the difference between a world containing either a non-tripartite or a tripartite God, angels and humans, and a world containing only humans.

Now, there might be thought to be a sense in which Hinduism defines Gods into existence, for, given a world containing a tripartite God, angels and humans, it is because of what Hindus count as a God that they see a world containing three Gods and not just one. There are clearly more Gods in the world arising from the Hindu conceptual scheme as opposed to the Islamic one, say. But there is a crucial sense in which conceptual schemes do not define religious entities into existence. For if, irrespective of which conceptual scheme is employed and what range of entities that

\footnotetext{
${ }^{27}$ But, a critic might object, why talk of adherents of different religious faiths employing different conceptual schemes rather than simply asserting that they disagree about conceptual-scheme independent facts? In response, if one rejects the analysis of religious belief systems in terms of conceptual schemes and hence rejects internalist pluralism, then one will require an alternative theory to address adequately the problems raised by religious diversity. I have argued elsewhere that internalist pluralism offers the best explanation of the diversity of religious belief and practice. See "Internal Realism and the Problem of Religious Diversity", op. cit.
} 
scheme deems targetable, only human agents are in fact successfully targeted, the substantive religious claims of Muslims, Christians and Hindus are false. So, regardless of one's conceptual scheme, if, as a matter of fact, only humans are successfully targeted, then neither Islam nor Christianity nor Hinduism can succeed in defining religious entities into existence. Given a conceptual scheme that targets only human agents, the atheist is correct. But interestingly, given a conceptual scheme that targets a tripartite God, angels and humans or a conceptual scheme that targets a nontripartite God, angels and humans, Muslims, Christians and Hindus could all be asserting true statements about religious entities, even though they sound as if they are contradicting one another. Moreover, this implies that when Muslims and Christians denounce Hindus for worshiping false Gods, they may well be only false Gods within the Islamic and Christian conceptual schemes. ${ }^{28}$ They are not false Gods in the manner in which they would be were only human agents there to be counted, as in an atheist's conceptual scheme.

Hence, internalist pluralism entails neither that atheism is false nor that it is true. Either might be the case. It all depends upon whether or not the only agents successfully targeted by any conceptual scheme are human. However, internalist pluralism does entail that even if the claims of one religion are found to be true, the seemingly counter-claims of other religions may be equally true (that is, true within their respective conceptual schemes). Consequently, while internalist pluralism does not generate religious entities out of nothing, it does entail that the ontological claims made by members of all faith traditions should be taken equally seriously. ${ }^{29}$ No

\footnotetext{
${ }^{28}$ Similarly, statements made about W1 and W2 may appear contradictory even though they are not in fact contradictory if we take into account that they are governed by the conventions of different conceptual schemes. Put another way, the statements may not in fact be incompatible, even though the conceptual schemes are. One cannot simultaneously employ the conceptual schemes of the "Carnapian" and the "Polish Logician," just as one cannot, on the account suggested above, consistently employ both the conceptual scheme of a Hindu and that of a Christian.

${ }^{29}$ It might be objected that one who subscribes to internalist pluralism would be committed to applying the theory at the meta-level, and thus regarding, for example, internalist pluralism and transcendental pluralism as incommensurable conceptual schemes to be taken equally seriously. If this were the case, internalist pluralism may well be deemed incoherent (as William Alston has argued with respect to internal realism), because it would seem to imply that conceptual schemes require analysis by metaconceptual schemes, which require analysis by meta-meta-conceptual schemes, and so on ad infinitum. However, internalist pluralism is a theory about conceptual schemes and the way that they relate to
} 
ontological claim can be presumed to be false merely because it appears to contradict an ontological claim that is taken to be true within the context of another faith tradition. This is a conclusion which metaphysical realists have typically been keen to avoid. ${ }^{30}$ However, the ability to regard as possibly true the ontological claims made by adherents of a variety of faith traditions, ${ }^{31}$ even when these appear to contradict the ontological claims of one's own conceptual scheme, would seem to be an advantage in a multicultural environment where members of diverse faith traditions, and those of none, often live side by side.

I have indicated how those subscribing to different religious traditions could make different sounding statements about religious entities that were nevertheless true within each of their conceptual schemes. However, this is not to say that all differences between faiths are of this sort. For example, if a Muslim were to insist that it is not that she does not count a tripartite division within God as involving three divine entities, but that there is nothing tripartite about God at all, then this kind of disagreement between the Muslim and the Christian is more like the disagreement between the atheist and the believer. It is more like the "Polish Logician" saying that she understands the "Carnapian" way of counting objects, and on seeing the world of Figure 1, insists that when a "Carnapian" claims that there are three objects, then the "Carnapian" is simply mistaken.

each other. While one could apply it at the meta-level, one does not have to. Thus, as I have argued at length elsewhere, internalist pluralism is not susceptible to this objection. See "Internal Realism and the Problem of Religious Diversity”, op. cit., pp. 298-300. For Alston's criticism of internal realism, see Alston, A Sensible Metaphysical Realism, op. cit., pp. 32f.

${ }^{30}$ Keith Yandell, for example, points out that the central beliefs of major world religions such as Theravada Buddhism, Jainism, Advaita Vedanta Hinduism and Generic Philosophical Monotheism (which is an abstraction of Judaism, Christianity and Islam), all include ontological claims that contradict the ontological claims made by those within the other three traditions. He argues that if the ontological claims of any one of these traditions were proven to be true, that would entail the falsity of the central beliefs of the other three religious traditions. Internalist pluralism denies this entailment. See Keith E. Yandell, Philosophy of Religion: A Contemporary Perspective (London: Routledge, 2002), $\mathrm{p}$. 34.

${ }^{31}$ Presumably one could regard such claims as possibly true even while conceding that one's ability to understand them might be limited by one's ignorance of the conceptual scheme employed by the claimants. This is not to say that the ability to regard the ontological claims of different religious conceptual schemes as possibly true entails that one will regard all these claims as "live options" for oneself, given the conceptual scheme which one actually employs. 
However, the difference between Figure 1 and Figure 2 merely concerns counting atoms, on the one hand, and counting atoms and mereological sums, on the other. The conceptual schemes that people actually employ are far, far richer; ranging over many different kinds of entities, including the religious, the aesthetic and the moral. And within each rich conceptual scheme all of the various components will interrelate and cohere in some complex way. Thus, translating from one conceptual scheme into another may, in practice, prove to be extremely difficult. And one new to a conceptual scheme may fail to see all features of the world that are evident to those with a long familiarity with that conceptual scheme (just as it is difficult for the novice to identify instances of all of the kinds of fish represented on a fish chart). All of this makes it very difficult for those within one conceptual scheme to be certain that the claims made by those within a different conceptual scheme are false. Surely, acknowledging this difficulty can sensitize one to the need to avoid dogmatism when forming judgments about the truth-value of beliefs held by members of faith traditions other than one's own.

\section{VI}

I have argued that the adherent of internalist pluralism can deploy a distinction between conceptual-scheme targetability and successful conceptual-scheme targeting. In the religious domain, the question of conceptual-scheme targetability may well, at least at times, be what is at issue between those subscribing to different varieties of theism - and that disagreement concerns how the fundamental religious entity is to be construed. However, the question of successful conceptual-scheme targeting would seem to be what is at issue between the atheist and the religious believer-and this concerns whether there are any fundamental religious entities to be counted, given any of the available religious conceptual schemes. ${ }^{32}$

\footnotetext{
${ }^{32} \mathrm{~A}$ common criticism of Hickean transcendental pluralism is that it portrays morally motivated atheists as responding to the same ultimate religious reality as religious believers are thought to be responding to. This strikes many critics as highly implausible and also patronizing to atheists who, in effect, are being described by Hick as "anonymous theists". Internalist pluralism's account of atheists suffers from neither of these disadvantages.
} 
However, as I briefly mentioned earlier, it might be argued that there is one variety of religious claim that could not possibly be conceptual-scheme dependent in any way: namely, all claims about God being transcendent to the world. For if a conceptual scheme determines what is to count within a world, then, it might be assumed, "God" must be conceptual-scheme independent in transcending the world. But, by way of response, what would count as a transcendent God may differ from one religious tradition to another. In other words, what it means to transcend the world and what it means to be a God that does so is no less conceptual-scheme dependent than any other claim. Put another way, claims about God's transcendence are no less made within a conceptual scheme than are the divergent claims of the "Carnapian" and the "Polish Logician". As such, there is a sense in which a transcendent God is within the "world" of a conceptual scheme.

But is it not paradoxical to state that a God that is transcendent to the world is nevertheless within the world? The paradox is only apparent, for, clearly, there are two senses of "world" that need to be distinguished: a narrow sense, where what is meant by "world" is such that God transcends it; and a wider sense, where everything that can be talked about, including a transcendent God, is within it. But then, given the latter sense of "world", when an adherent of one faith makes claims about a transcendent God that appear to contradict claims about such a God made by the adherents of another faith, then the disagreement could be analogous to that of the "Carnapian" and the "Polish Logician". While it sounds as if the "Carnapian" and the "Polish Logician" are contradicting each other when one counts three objects and the other denies that there are only three and insists that there are seven, instead, the contradiction is only apparent. For they are not talking about the same things. The same could be the case with divergent-sounding claims about a transcendent God. Hence, a believer's citing the transcendent nature of her God provides, on its own, no excuse for her showing intolerance to the claims made by those adhering to a different faith.

In short, if differences between the claims of religious belief systems are of the wholly conceptual-scheme dependent variety, this would constitute strong grounds for religious toleration. This is because, presuming that the claims comprising the belief 
systems of the major world religions are equally internally coherent, ${ }^{33}$ there would seem to be no compelling justification for preferring one religion rather than another. ${ }^{34}$ And while internalist pluralism provides a theory that can underwrite the appropriateness of believers showing toleration to those of different faiths, it would not seem to close the debate between religious believers and atheists. This latter debate must take place across a variety of fields of human knowledge: not only philosophy, theology, and religious studies, but also anthropology, sociology, psychology, and even the natural sciences. ${ }^{35}$ Pending a clear outcome, internalist pluralism counsels believer and atheist alike to adopt a stance of mutual toleration. ${ }^{36}$

\section{Acknowledgement}

I am grateful to Alan Carter for his comments on an earlier draft of this article.

\footnotetext{
${ }^{33}$ This presumption has been ably defended in John Hick, “On Grading Religions”, Religious Studies 17, 4 (1981): 451-467, and in Dan Cohn-Sherbok, Issues in Contemporary Judaism (London: Macmillan, 1991).

${ }^{34}$ While there may be no justification for preferring one religion to another that is internal to the religious conceptual schemes themselves, this is not to deny that there may be other, more practical, reasons in favor of commitment to one religion rather than another.

${ }^{35}$ Needless to say, this list is not exhaustive.

${ }^{36}$ Tolerance, of course, may be insufficient as a starting point for inter-faith dialogue. See Perry Schmidt-Leukel, "Beyond tolerance: towards a new step in interreligious relationships", Scottish Journal of Theology 55 (2002): 379-391.
} 